The thrust of this well written book brimming with battles, caliphs and kings, and insights into the cultural and intellectual formation of early medieval Europe, is that Europe's rise would not have been possible without the civilisational fertilisation which Islamic presence in Andalusia bestowed. In an interesting convergence with the thesis presented 30 years ago by the reputable Tunisian thinker Hichem Djaït, ${ }^{4}$ Lewis confirms that the history of modern Europe (and by extension, the globalised Euro-American system now in place) was brought about in large part as a reaction to Islam. This realisation may serve as a starting point for re-thinking the civilisational needs of Muslim societies now dominated by a powerful mercantile and military 'West'.

\title{
Notes
}

1. N. Daniel, The Arabs and Mediaeval Europe (London and New York: Longman, and Beirut: Librairie du Liban, 1979, 2nd ed.); the third of Daniel's great trilogy on the historical unfolding of mutual perceptions between Islam and Europe, that began with his classic Islam and the West: The Making of an Image (Edinburgh: Edinburgh University Press, 1960). Daniel exploited the original Latin and Arabic sources and made major contributions to our understanding of the reciprocal engagement between pre-modern Europe and Islam. Interestingly, Lewis ignores Daniel's work.

2. To be precise: 360 stone posts or 'idols' ringing the cubic centre, since the $\mathrm{Ka}$ ' $\mathrm{bah}$ in most ancient times functioned as a solar calendrical device akin to Stonehenge and similar structures extant across Europe and North America. Few Muslims realise this today, of course.

3. Lewis makes clear his dependence on Orientalist discourse when he twice approvingly cites (pp. 374 and 421 n.17) the tribute paid to Ibn Rushd's great influence in thirteenth-century Christian Europe on the authority of that great doyen of neo-Thomist Catholic intellectuals, Etienne Gilson: "Rationalism was born in Spain in the mind of an Arabian philosopher as a conscious reaction against the theologism of the Arabian divines." Lewis here cites E. Gilson's Reason and Revelation in the Middle Ages (1938). See also Majid Fakhry, Averroes: His Life, Works and Influence (Oxford: Oneworld, 2001), xv-xvi.

4. Hichem Djaït [Ja'ît], Europe and Islam: Cultures and Modernity, trans. P. Heinegg (Berkeley CA: University of California Press, 1985) - a work that still merits reading today.

\section{Umer Chapra - Muslim Civilization: The Causes of Decline and the Need for Reform}

(Leicester, United Kingdom: The Islamic Foundation, 2008), paperback, xxii +225 pp. ISBN: 978-0-86037-4619, £13

\section{Ibrahim Umar University of Leicester, United Kingdom}

Chapra's book comes at a time when it is most needed. This is an era of upheavals and attempts at 'revivalism' in the Muslim communities and countries across the world. Chapra examines the factors responsible for the decline in Muslim civilisation and tries to offer suggestions on alternative routes for the Muslim world to regain its rightful position among the world's civilisations. 
The book begins with raising some fundamental questions as to the reasons behind the current material and moral bankruptcy throughout much of the Muslim world. The author points at the contemporary disparity between the natural resources in the Muslim world and its poor indices of development. He argues that Islam was once a leading civilisation and a beacon for humanity. According to the author, its eclipse led to the crucial question of what has gone awry. Is the religion of Islam with its ideals, approaches and teachings 'burned out' or is the fault solely to be sought among its followers? Chapra tries to find answers by searching among the qur'ānic sources for factors responsible for the 'downfall' of any people such as the inability to initiate positive changes within themselves, loss of family values and bad governance. Chapra applies Ibn Khaldūn's (d. 1406) theory of development and decline - to be found in his famous Muqaddimah or 'introduction to history' - as his theoretical framework and justifies his preference of this theory over other alternative models such as those offered by Edward Gibbon (d. 1794), Oswald Spengler (d. 1936) and Paul Kennedy (b. 1945).

In his first chapter, Chapra tries to explain Ibn Khaldūn's model by considering the following themes: (a) the role of human beings; (b) the role of development and justice; (c) the role of institutions and the government; (d) the role of wealth; (e) the role of trigger mechanisms. He concludes the chapter by offering a critique of Ibn Khaldūn's model pointing at its strength and shortcomings.

The second chapter examines the factors that contributed to the rise of Muslim civilisation in history and stresses the transformation of the backward early Muslim community - characterised by "bitter internecine feuds, paucity of resources, a harsh climate, difficult terrain, and excruciating poverty [...]" (p. 34) - by the Prophet of Islam from absolute obscurity to a global beacon.

Chapra devotes his third chapter to an examination of the factors responsible for the general decline of Muslim civilisation. He makes an attempt at debunking Kuran's assertion that factors such as the absence of primogeniture, the lack of the concept of limited liability and legal personality in Islam, and the decline of the Islamic institution of waqf or charitable trusts, are responsible for the decline of Islamic civilisation. He also reiterates the issue of whether 'moral degeneration' is to be considered the main cause of Muslim decline. Chapra concludes that 'moral degeneration' alone does not adequately explain the causes of Muslim backwardness today. Other contributing factors, such as political oppression, tyranny and the subversion of the true and original meaning of khiläfah and responsible government in Islam need to be taken into consideration as well.

The fourth chapter is devoted to the economic decline of the Muslims. Chapra attributes to this decline fiscal imbalances, the allocation of massive land grants to the ruling family, unjust taxation, currency devaluation, external borrowing, corruption, the trading of political favours and the inability to develop physical infrastructures. 
Similarly, in his fifth chapter Chapra tries to make out the reasons for decline in Muslim education, science and technology - a decline that reversed the huge strides made by the Muslims earlier in those crucial areas. Chapra believes that decline in state-funding and the inability to involve the private sector were responsible for the decline in these three crucial fields. He also introduces the reader to how the conflict between the rationalist and the conservative Muslim philosophers contributed to the decline in Islamic civilisation in general. In analysing the debate, he refers as examples to Al-Ghazālī (d. 1111) and Ibn Rushd (d. 1198), representing the 'conservative' and 'rationalist' schools of thought, respectively. He concludes this chapter by demonstrating how the increasing slide towards conservatism in the Muslim world led to the ultimate decline of Islam as a world civilisation. Chapra also makes an attempt at peering into the future of rationalism in the Muslim world. Likewise, he presents a comparative evaluation of Muslim and Western enlightenment movements.

The sixth chapter discusses the factors responsible for the social decline in the Muslim world. Notable among these factors were the yawning gap between the government and the people, the stagnation of fiqh, the role of Sufism which abstains from world pursuits as well as the deterioration in the position of women.

The seventh chapter draws some lessons from Islamic history. Chapra addresses the reasons for the negligence of their responsibilities from the part of Muslim rulers, the loss of the freedom of expression, the futile attempt by political authorities to inculcate positive values among the people, the loss of legitimacy by Muslim tyrants and the quest for external (non-Muslim) support. Chapra concludes by stating that Islam per se is not to be considered the cause of the decline of Muslim civilisation as a whole but itself, "a victim of lack of political accountability, corruption and repression" (p. 155).

In his eighth chapter, Chapra argues that the Muslim world failed to learn lessons from its past. Like the proverbial fool, the Muslim world kept stumbling over the same stone. The absence of democracy, lack of freedom of the press and a poor human development index continue to plague the Muslim world.

In the last chapter of this insightful book, Chapra makes a case for the urgent need for reform in the Muslim world. He advocates moral reforms, the establishment of justice, development and poverty alleviation, investment in education and microfinance, as well as institutional and political changes. Chapra suggests that globalisation, enlightenment and democratisation in the contemporary world would also lead to a more favourable climate for change among the Muslim ummah. Although he admits that the path to reform in the Muslim world is paved with thorns, he seems to believe that peaceful struggle is the only way of bringing reforms to the Muslim world.

However, it is rather disappointing to notice throughout the work that the author has failed to demonstrate how external forces, particularly Western ones, have 
contributed to the decline of the Muslim world - by way of invasion, colonisation, and division. Rather naïvely, Chapra seems to believe that the Western world could 'help' the Muslim world to restore its lost glory. He offers his gratitude to the West for what he describes as its 'humanitarian' help to the Muslim world. He seeks to apologetically admonish the West for the damage that its adventures are causing in Iraq and Afghanistan and its support for Israeli aggression in Lebanon and Palestine. His attempt in this section simply reveals his poor comprehension of international relations and politics of international development.

On the other hand, Chapra has done a good job in kindling a lively debate on the important issue of diagnosing the ailments of the Muslim world and prescribing alternative solutions. However, the reader would have expected him to cite and criticise other works that have also focused on the causes of decline in Muslim civilisation and the need for reform. As a matter of fact, Chapra does mention a few works cursorily. However, those works offer no comprehensive diagnosis on the problems confronting Muslims today. Likewise, the author could have substantiated why the reader should believe in his suggestions as to how the Muslim world could regain its glory. Reference to other comparative sources could have helped the reader to know what others prescribe as solution, what are the similarities and differences in their argument, and why the author's recommendations should be taken seriously. In similar vein, Chapra should have tried to offer an evaluation of the contemporary attempts by reformist groups in the Muslim world and should have presented some of the lessons from their various approaches. Chapra should have offered an in-depth critique of the different approaches. The limited space he devotes to Islamic movements is largely descriptive and presents rather unsubstantiated recommendations. Likewise, the reader misses an in-depth examination on whether the historical decay in Muslim civilisation was purely an inside factor or the result of other external forces such as Western intervention. The author is also silent on the effects that other important issues, such as the 'war on terror', can have on Islamic revivalism. In spite of those and other similar shortcomings, however, Chapra's book should be considered an important contribution in the current 'revival of Islamic civilisation debate'.

\section{Muhammad Arif Zakaullah - The Cross and the Crescent: The Rise of American Evangelicalism and the Future of Muslims}

(Kuala Lumpur: The Other Press, 2004), paperback, xii + 269 pp. ISBN 983-9541-42-0

\section{N. Doran Hunter Minnesota State University at Mankato, United States}

Socrates, the great Athenian philosopher, once said that self-regard, self-knowledge and self-control would lead men to sovereign power. The idea was that through 